\title{
Love bites: male frogs (Plectrohyla, Hylidae) use teeth scratching to deliver sodefrin precursor-like factors to females during amplexus
}

\author{
Lisa M. Schulte ${ }^{1 *} \mathbb{C}$, An Martel $^{2}$, Raciel Cruz-Elizalde ${ }^{3}$, Aurelio Ramírez-Bautista ${ }^{4}$ and Franky Bossuyt ${ }^{5}$
}

\begin{abstract}
Background: Efficient transfer of chemical signals is important for successful mating in many animal species. Multiple evolutionary lineages of animals evolved direct sex pheromone transmission during traumatic mating - the wounding of the partner with specialized devices - which helps to avoid signal loss to the environment. Although such direct transmission modes of so-called allohormone pheromones are well-documented in invertebrates, they are considered rare in vertebrates. Males of several species of the frog genus Plectrohyla (Hylidae, Anura) have elongated teeth and develop swollen lips during the breeding season. Here we investigated the possibility that these structures are used to scratch the females' skin and apply allohormone pheromones during traumatic mating in several Plectrohyla species.
\end{abstract}

Results: Our behavioural observations revealed that males press their upper jaw onto the females' dorsum during amplexus, leaving small skin scratches with their teeth. Histological examinations of the males'lips identified specialized mucus glands, resembling known amphibian pheromone glands. Whole-transcriptome sequencing of these breeding glands showed high expression of sodefrin precursor-like factor (SPF) proteins, which are known to have a pheromone function in multiple amphibian species.

Conclusions: Our study suggests SPF delivery via traumatic mating in several anuran species: the males have specialized breeding glands in the lips for production and secretion and use their elongated teeth as wounding devices for application. We hypothesize that these SPF proteins end up in the females' circulatory system, where understanding their exact function will require further molecular, physiological and behavioural testing.

Keywords: Chemical communication, Breeding glands, Amphibia, Amplexus, Allohormone pheromones, Traumatic mating, Sodefrin precursor-like factor

\footnotetext{
${ }^{*}$ Correspondence: Schulte@bio.uni-frankfurt.de

${ }^{1}$ Department of Wildlife-/Zoo-Animal-Biology and Systematics, Faculty

of Biological Sciences, Goethe University Frankfurt, Max-von-Laue-Str. 13, 60438 Frankfurt/Main, Germany

Full list of author information is available at the end of the article
}

\begin{abstract}
Background
The oldest and most widespread intraspecific communication system involves chemical signals and can be found in aquatic as well as terrestrial vertebrates $[1,2]$. Chemical signals released in the environment by one individual and detected by specific devices of another, where they induce a specific reaction, are defined as pheromones [3]. However, environmental constraints such as temperature, humidity, wind and water currents influence
\end{abstract} original author(s) and the source, provide a link to the Creative Commons licence, and indicate if changes were made. The images or other third party material in this article are included in the article's Creative Commons licence, unless indicated otherwise in a credit line to the material. If material is not included in the article's Creative Commons licence and your intended use is not permitted by statutory regulation or exceeds the permitted use, you will need to obtain permission directly from the copyright holder. To view a copy of this licence, visit http://creativecommons.org/licenses/by/4.0/. The Creative Commons Public Domain Dedication waiver (http://creativeco mmons.org/publicdomain/zero/1.0/) applies to the data made available in this article, unless otherwise stated in a credit line to the data. 
the longevity and arrival of these signals and therefore can limit the effectiveness of communication via pheromones [2, 4]. Animals developed different solutions to this problem, such as long living carrier proteins which slowly release volatile pheromones (e.g. major urinary proteins in mice [5]), by properly navigating air- and water currents towards a pheromone source (e.g. in moths, crabs, and lobsters; for review see [6]), or by fanning pheromones in the direction of the receiver (e.g. in aquatic newts [7]). Another option is the direct transmission of pheromones, hence avoiding any signal loss to the environment. These kind of pheromones can be transferred directly to the nose of the receiver (e.g. during copulation in anurans [8]) or by wounding the mating partner with specialized devices (i.e. traumatic mating, traumatic secretion transfer [9]). The chemicals transferred during traumatic mating are not classified as regular pheromones, but are defined as primer pheromones [10], allohormones [11, 12] or allohormone pheromones [13]. The latter term, allohormone pheromone, takes into account that these chemicals behave similar to hormones (hence allohormones [11]), but that the same class of molecules may also act through the sensory organs in other species (hence defining them as a subclass of pheromones [2]). Allohormone pheromones are, for example, delivered via love-darts in snails (Cantareus asperses), increasing the transmitters paternity [14], or via copulatory setae in earth worms (Lumbricus terrestris), increasing the sperm uptake of the receiver [15]. Only a single example is currently known from vertebrates: salamanders of the family Plethodontidae possess mental glands beneath the chin, which have been shown to contain courtship pheromones that positively influence the female's receptivity [16-18]. While in some species these molecules are transferred through the nose, in other species (e.g. Desmognathus ochrophaeus) they are transferred by males scraping them with protruding premaxillary teeth through the female's skin directly into her circulatory system, i.e. inoculating her with allohormone pheromones [19-21]. The chemical signals used during salamander courtship are typically protein pheromones, used for short-range communication (for an overview of the different types of amphibian pheromones see [2224]). Although some of these proteins have been shown to have originated early in amphibian evolution and can be found among several urodele and anuran families [8, $25,26]$, their transmission via traumatic mating using extra-genital wounding structures [9] is currently only known from these salamanders.

In Neotropical anurans of the genus Plectrohyla, breeding males of all species of the Plectrohyla guatemalensis group [27, 28] possess swollen upper lips as well as protruding maxillary and premaxillary teeth [29-31]. It has been suggested that this combination may have a similar function as the allohormone pheromone inoculation apparatus of plethodontid salamanders [31]. This hypothesis is supported by few observations of Plectrohyla in amplexus, during which the male presses its teeth and swollen upper lips against the top of the head of the female [31, 32], the discovery of a female $P$. hartwegi exhibiting several parallel scratches on her head and back [31], as well as by a study connecting the teeth position with potential pheromone glands in one Plectrohyla species [33]. Allohormone pheromones positively influencing the female's receptivity (e.g. resulting in accelerated oviposition) should be of especially great advantage for mating anurans. Being joined in amplexus for several hours or days [34] makes frogs extremely vulnerable to predation $[35,36]$ and accelerating this process should largely improve their fitness [37]. Here we investigated the possibility of traumatic mating and potential allohormone pheromone transmission in several Plectrohyla species by combining histological, morphological and behavioural data, whole transcriptome sequencing (RNAseq) and molecular phylogenetics (compare Table 1).

\section{Results}

Mating behaviour and extra-genital wounding structures During field work in Mexico, we kept a couple of $P$. sagorum in amplexus in captivity for $24 \mathrm{~h}$ and observed their mating behaviour. During this time, we observed the male pressing its upper jaw against different areas of the female's dorsum (Fig. 1A, B). After separating and

Table 1 Plectrohyla species used for the different methods applied

\begin{tabular}{llll}
\hline & P. sagorum & P. matudai & P. hartwegi \\
\hline Behavioural observations (mating) & $\checkmark$ & \\
Teeth length comparison between males and females & $\checkmark$ & $\checkmark$ \\
Distance between male teeth vs. Female scratches & $\checkmark$ & $\checkmark$ \\
Microscopic structures of lip glands & $\checkmark$ & $\checkmark$ \\
Lip gland protein expression and phylogenetic analysis & $\checkmark$ & $\checkmark$ \\
\hline
\end{tabular}




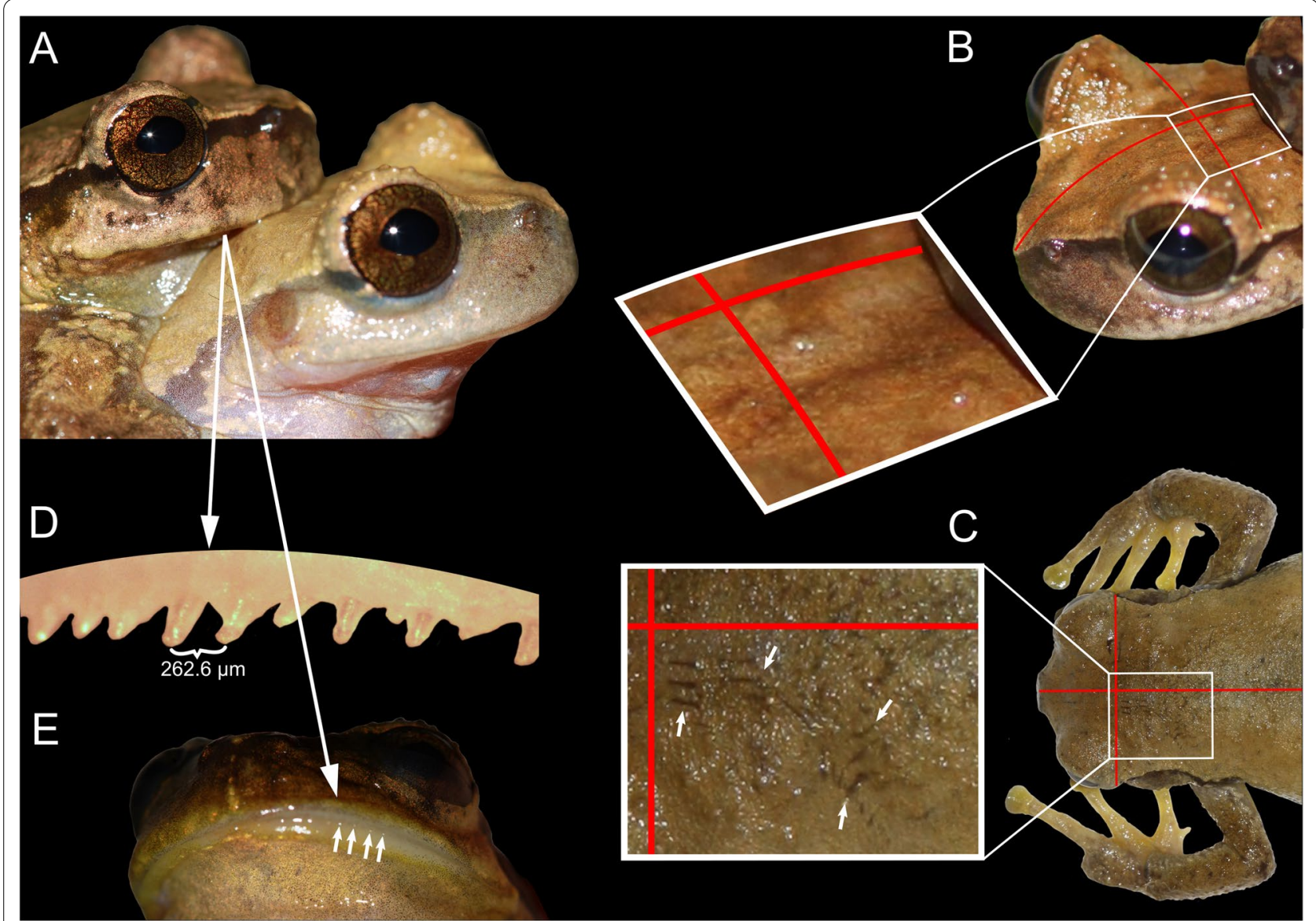

Fig. 1 Plectrohyla sagorum traumatic mating. A Male P. sagorum pressing his lips on the female's head during amplexus. Female skin before (B) and after $(\mathbf{C})$ the male scratched over her head. White arrows are indicating some of the scratches. $\mathbf{D}$ Pointed teeth of the male, which are protruding through the swollen lips (E; pointed out by white arrows). Comparing the position of the males' head in (A) and (B) emphasises the movement of his lips over the females' dorsum

euthanizing both frogs, short parallel scratches were visible on the female's dorsum (Fig. 1C), which were not present earlier during amplexus (Fig. 1B). When measuring the distances between those scratches parallel to each other (ranging from 184.32 to $402.44 \mu \mathrm{m}$; mean $=311.23 \pm 69.21 \mu \mathrm{m})$ as well as the distances between the male's upper teeth (ranging from 170.46 to $438.64 \mu \mathrm{m}$; mean $=287.48 \pm 61.41 \mu \mathrm{m}$; Fig. $1 \mathrm{D})$ protruding trough his swollen lips (Fig. 1E), scratches and teeth match up well with each other. The same was the case when we compared the mean distance between the parallel running scars on the dorsum of the female $P$. hartwegi found by Duellman and Campbell [29] (ranging from 332.38 to $558.55 \mu \mathrm{m}$; mean $=435.49 \pm 69.87 \mu \mathrm{m}$ ) with the teeth distance of a conspecific male (although it was not from the same locality; ranging from 228.56 to $694.76 \mu \mathrm{m}$; mean $=387.33 \pm 105.41 \mu \mathrm{m}$; see also Fig. 2). The well preserved scars of $P$. hartwegi, however, seem to be deeper than those in $P$. sagorum, which after storage in formaldehyde became less visible. This might be correlated either with a difference in intensity of scratching the skin, or with the shape of the teeth in these two species: while $P$. hartwegi has wider spatulate teeth (Fig. 2B), P. sagorum's teeth are pointed (Fig. 1D). In both species, males have on average stronger protruding teeth than conspecific females and the same is the case for another congeneric species $P$. matudai (see Table 2).

\section{Microscopic structures of lip glands}

Histological examinations of skin samples from the lip and dorsal region of the three examined Plectrohyla species show that the dorsal skin in males and females exhibits the usual structure of anuran skin, containing mainly so-called ordinary serous glands, as well as some scattered ordinary mucous glands (see Fig. 3). The glands found in the lips, however, deviate strongly from this pattern. Here no serous glands, but only mucous glands can be found. When comparing the lip sections between 


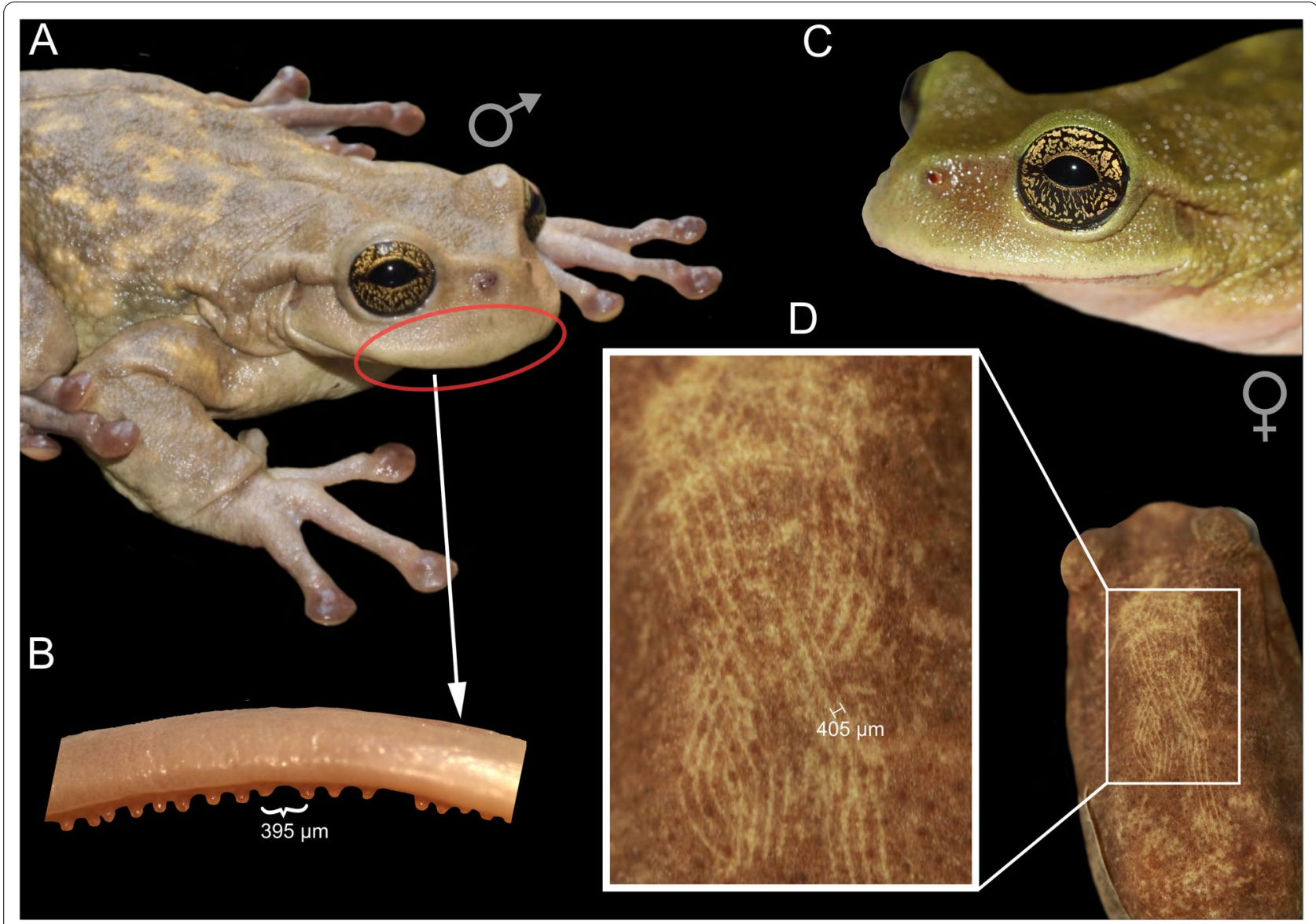

Fig. 2 Evidence for traumatic mating in Plectrohyla hartwegi. A Male P. hartwegi with swollen lips. B The male's spatulate teeth protrude through the lips and are most likely used to scratch the female (C) during amplexus. D shows the potential teeth marks on the back of a female (museum specimen UMMZ 152864)

Table 2 Mean teeth length and mean thickness of the glandular region in the lips of Plectrohyla males and females. For males additionally the mean diameter of specialized mucus glands was measured

\begin{tabular}{|c|c|c|c|c|}
\hline Species & Sex & Mean teeth length $(\mu \mathrm{m})$ & $\begin{array}{l}\text { Mean thickness of glandular } \\
\text { region }(\mu \mathrm{m})\end{array}$ & Mean SMG diameter $(\mu \mathrm{m})$ \\
\hline \multirow[t]{2}{*}{ P. hartwegi } & male & $189.982 \pm 33.819$ & $437.08 \pm 27.69$ & $155.77 \pm 20.15$ \\
\hline & female & $129.054 \pm 56.743$ & $151.04 \pm 13.96$ & \\
\hline \multirow[t]{2}{*}{ P. sagorum } & male & $150.868 \pm 54.601$ & $144.45 \pm 5.45$ & $95.70 \pm 4.05$ \\
\hline & female & $77.818 \pm 15.977$ & $71.97 \pm 4.42$ & \\
\hline \multirow[t]{2}{*}{ P. matudai } & male & $171.469 \pm 62.685$ & $142.74 \pm 10.19$ & $69.93 \pm 17.45$ \\
\hline & female & $82.391 \pm 21.866$ & $89.19 \pm 9.18$ & \\
\hline
\end{tabular}

sexes, we found that the glandular region is 1.6 to 3 times thicker in males than in females (Table 2). While the female glands are ordinary mucous glands (OMGs), the glands found in the male lips are specialized mucous glands (SMGs), i.e. breeding glands (as defined by [38]). Unlike the rather flattened OMGs, the Plectrohyla SMGs are round or longitudinal oval-shaped with a short intra-epidermal duct (where visible). Their secretory portions have radially arranged tall cells (with basal nuclei), projecting into the relatively wide devoid central lumen (Fig. 3). Plectrohyla hartwegi, being the biggest of the three examined species, has the largest SMGs, compared to $P$. sagorum and P. matudai (Table 2). While the SMGs in this species are organized in several layers, in the other 


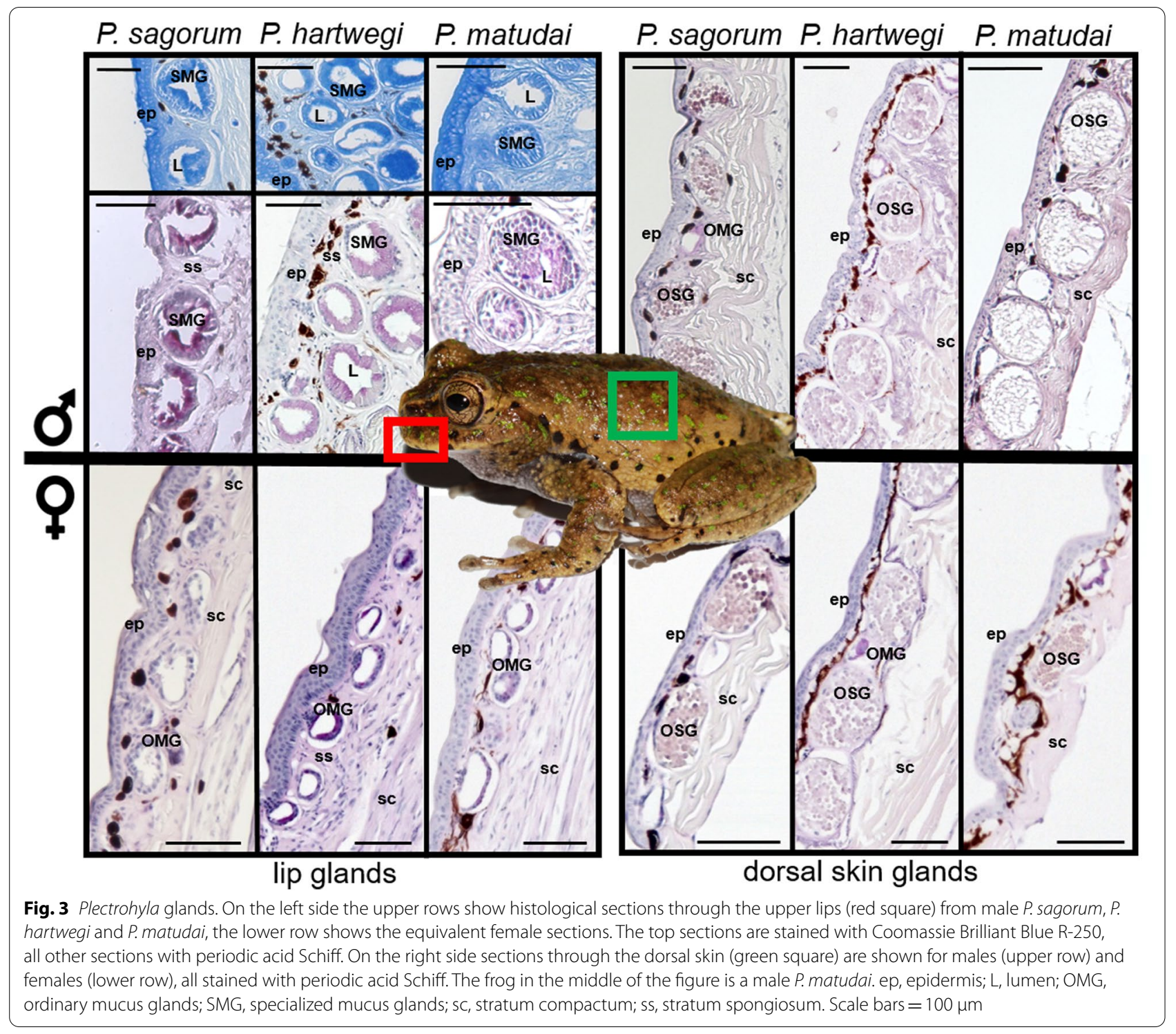

two species they are arranged in a single layer along the epidermis (compare Fig. 3). The glands occur along the inner and outer portion of the lip, with the gland ducts exiting throughout the entire width of the lips with no specific cognizable pattern. Staining reactions to PAS and Coomassie Blue R250 were positive for all SMGs.

\section{Secretory lip gland protein expression analysis and phylogenetic analysis}

To identify the proteins specifically expressed in the gland tissue of the frogs, we conducted whole-transcriptome sequencing (RNA-seq) on the gland-containing swollen upper lips of the males of two of the Plectrohyla species. Our results revealed the expression of several proteins that in other animals are known to be involved in egg development, fertilisation, locomotor processes, blood pressure and metabolic regulation (see Table 3). Interestingly, we also found high expression of several two-domain three-finger proteins (2D-TFPs) (P. sagorum: 10 different 2D-TFPs, 3 of which make up for $75 \%$ of the in total $>17,800$ transcripts per million [TPM]; P. matudai: 16 different 2D-TFPs, 3 of which make up for $75 \%$ of the in total 10,000 TPM) termed sodefrin precursor-like factors (SPFs). These SPFs show protein sequence identities of up to $96 \%$ within Plectrohyla, while identities with other amphibian SPFs are up to $61 \%$ for anurans and up to $41 \%$ for salamanders. Structurally, there is a minor variation in the cysteine arrangement of Plectrohyla sequences compared to most other amphibian SPF sequences (Fig. 4A), while 
Table 3 Selection of BLAST homologies found in Plectrohyla lip glands and their known functions in other animals. PS=P. sagorum, $\mathrm{PM}=$ P. matudai; ${ }^{* * *} \geq 5000,{ }^{* *} \geq 2500,{ }^{* *} \geq 1000,{ }^{*} \geq 500$ (in parenthesis = expression level below 50 TPM)

\begin{tabular}{|c|c|c|c|c|}
\hline Protein homology & $\begin{array}{l}\text { Extract of known functions in } \\
\text { other species }\end{array}$ & $\begin{array}{l}\text { Main location of expression in } \\
\text { other taxa }\end{array}$ & Expression level & References \\
\hline $\begin{array}{l}\text { 2D-TFPs (e.g. sodefrin precursor-like } \\
\text { factor, phospholipase A2 inhibitor) }\end{array}$ & $\begin{array}{l}\text { Sex pheromones, toxins, cholinergic } \\
\text { signalling, immune regulation, } \\
\text { Phospholipase inhibition }\end{array}$ & Sex glands; various organs & $P S^{* * * *}, \mathrm{PM}^{* * * *}$ & {$[44,45,84]$} \\
\hline $\begin{array}{l}\text { Kazal-type inhibitors (Ovomucoid- } \\
\text { like) }\end{array}$ & $\begin{array}{l}\text { Protease inhibitor (e.g. Trypsin), egg } \\
\text { protein, possibly secretion protec- } \\
\text { tion }\end{array}$ & Oviduct (liver) & $P S^{* *}, P^{* * * *}$ & {$[85-87]$} \\
\hline Ovostatin & $\begin{array}{l}\text { Protease inhibitor (e.g. Trypsin), egg } \\
\text { protein, possibly secretion protec- } \\
\text { tion }\end{array}$ & Oviduct & $P S^{* *}, \mathrm{PM}^{* *}$ & {$[86-89]$} \\
\hline $\begin{array}{l}\text { Vitelline membrane outer layer } \\
\text { protein I (VMO-I) }\end{array}$ & $\begin{array}{l}\text { Egg membrane protein; ovomucin } \\
\text { expression, antimicrobial barrier for } \\
\text { eggs }\end{array}$ & Oviduct & $P S^{* *}, P^{* * *}$ & {$[90,91]$} \\
\hline Fish-egg lectin & Egg protein, antimicrobial & Ovary (but also other organs) & PS, PM & [92] \\
\hline Jeltraxin & $\begin{array}{l}\text { Egg protein, binds calcium (pot. } \\
\text { Fertilization facilitation) }\end{array}$ & Oviduct & $P S, \mathrm{PM}^{*}$ & [93] \\
\hline Avidin & $\begin{array}{l}\text { Egg protein, binds biotin (pot. } \\
\text { Bacterial growth inhibition) }\end{array}$ & Oviduct & PS, PM & [94] \\
\hline $\begin{array}{l}\text { Cysteine rich secretory proteins } \\
\text { (CRISP-familiy; e.g. serotriflin-like } \\
\text { protein, MGC108118 protein precur- } \\
\text { sor) }\end{array}$ & $\begin{array}{l}\text { Involved in fertilization (sperm guid- } \\
\text { ance), antimicrobial, venoms }\end{array}$ & Uterus (some also other organs) & $P S^{* * *}, \mathrm{PM}^{* *}$ & {$[87,95-98]$} \\
\hline Beta-microseminoprotein & $\begin{array}{l}\text { Seminal plasma protein, antibacte- } \\
\text { rial, antifungal }\end{array}$ & Prostate (but also other organs) & $P S^{*}, \mathrm{PM}^{*}$ & {$[99,100]$} \\
\hline $\begin{array}{l}\text { Thyrotropin releasing hormone } \\
\text { (TRH) }\end{array}$ & $\begin{array}{l}\text { Influence on reproductive behav- } \\
\text { iour, locomotor activity }\end{array}$ & Hypothalamus & PM (PS) & [101-103] \\
\hline Tachykinin & $\begin{array}{l}\text { Gut tissue contraction, defensive } \\
\text { skin peptide, vasodilation, locomo- } \\
\text { tor stimulation }\end{array}$ & Various organs & PM (PS) & {$[104,105]$} \\
\hline Glucagon & $\begin{array}{l}\text { Blood sugar elevation, appetite } \\
\text { regulation }\end{array}$ & Pancreas & $(\mathrm{PM})$ & {$[47,57,106,107]$} \\
\hline Nucleobindin 2 peptide (NUCB2) & $\begin{array}{l}\text { Fat metabolism regulation, appetite } \\
\text { regulation }\end{array}$ & Spleen, testis and stomach & PS (PM) & [108] \\
\hline Resistin-like & $\begin{array}{l}\text { Peptide hormone derived from } \\
\text { adipose tissue, insulin-antagonist }\end{array}$ & Gastrointestinal tract & PM & [109] \\
\hline $\begin{array}{l}\text { Inactive pancreatic lipase-related } \\
\text { protein } 1 \text { (PL-RP1) }\end{array}$ & $\begin{array}{l}\text { Inhibitor of dietary triglyceride } \\
\text { digestion }\end{array}$ & Pancreas & PS, PM & [1 10] \\
\hline
\end{tabular}

the rest of the cysteine pattern is identical. Further protein pheromone sequences known from other amphibian species (such as amplexin or plethodontid modulating factor) were not found in the male lips.

Because SPF proteins are known for their pheromone function in several amphibians $[25,26]$, we analysed the phylogenetic position of our sequences to get a perspective on whether our SPF sequences fall into the same clades as those with known pheromone function. For this, we aligned our SPF sequences with a broad range of sequences from other amphibians and outgroup teleost fish sequences and performed phylogenetic analyses. Our

\footnotetext{
(See figure on next page.)

Fig. 4 Sequence similarities and evolutionary relationships between SPF proteins. (A) Alignment of selected beta-SPF transcripts (numbers refer to transcripts used in the tree (B)). Protein sequences show a typical $10+8$-cysteine pattern in the first and second motif, suggesting a high structural similarity (but note the slight deviation of cysteine position 2 in the second motif of the Plectrohyla sequences). (B) Maximum likelihood tree of 2-domain-TFPs (2D-TFP) from amphibians and teleost fish (outgroup). Anuran transcripts that originated from breeding glands are shown in green, salamander transcripts from breeding glands in blue (see Additional file 1). Nodes supported by all three assessment methods are indicated with a black circle, nodes only supported by one or two methods are indicated with blue, green and/or red (ultrafast Bootstrap > 95\%, red; SH-aLRT > 80\%, green; aBayes-support > 0.95, blue). Duplication events within the anuran SPF clade are marked with "D", other nodes within this clade are considered speciation nodes (Notung analysis). Numbers 1-5 are referred to in the text
} 
A

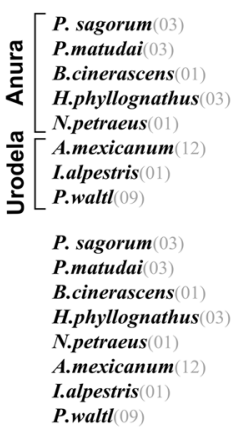

---LNCLSCL--SANSTVCEASEMDCPG--SQCMTASQYYHNGDKTFNSMYKGCANES---LCGLFGSLTQDPDVKIRVGAVCCSGEMCNIEVFNLPE--EDTK ---LNCLSCL--SANSTVCKASEMDCPG--SOCMTASQYYHNGNKT FNSLYKGCAHDS---LCGLYGSLTQDPDVVKIRVGAVCCSGEMCNIEVFNLPE--EDPK GPVLKCMOCK--TSDKEDCTGESVKCPNPGYVCAKGIEYDRIGEDITRTVYRGCLNRTD--ICGSTFOF-STIDSRYSSYHECCKKDNCNHGPIKMPT--RNTT ---LRCLECK--AEGKTNCPGQSVECMDKNDFCVTS IEYDILYGNITPTIRRGCMNVSK--VCDGT IAM-NSTGYQLMEHNDCCYT DNCNSGEI KMPK--INTT ---LSCICCKETGEGKQNCSGVIQQCANDNDTCATQI EYNNVDPDKKT TVKKSCLPAKDKNICQQPMFL-NADRFNMSLFTDCCDTDGCNTNNITMPP--KNTT ---IICEQCS----NINSCSGFFAPCPAEVTHCVKGLENSTVGSNVRLLAYKGCVDPSRQATCDKEVIF-RSSRMSLYITRECCDSDSCNSKNTKQAALRIPKT ---LICETCF--AAGATQCSGTFEQCSPDVTHCFKGVENTTAGGDVTVNVFKDCLDPSYQAVCGSAFHL-KNSVVSYWISTTCCDSDFCNRGDVEVPA--VDET ---LTCEQCF--AIHASTCSGIFTQCPPDVTHCFSGLENNTLGNDI I LTAFKGCLNPSQKVACGRQFSF-RSSEASLWMSRSCCDSDFCNGGDVQVPA--ADNT

PNGVKCPNSYCTGTTEEC---KSDKDIECTGSETKCIDYRGRVKNPDD-SVEDYSAKGC INPEGCFYNFQI L IKVEEIKGKLLKC- GTGFQCNSCVNVGNT-VCQEWKPKARIECRDKEAECEVFRGKVARAGR-QIKEFYASGCAIKGFCTNVVDAFIGTKI IESQYLSCTKTLNVRNWQY GNGLQCPSCFVEGGY-EC---NSHQPVSCSGNQRDCEIY IGKGYI PGTGQNKYYY I AGCTTGDTCEFGPLALVGAEVGVPRI LMCKAAQNME---LNGRQCDTCFVEGKL-QC---DDFKTVNCTGNQLQCFEYSGNATRPEH-NSEMFGEKGCVTYGTCFVDLNNLPGTEVGSNAVYSCT---------PNGFKCPDCDTDRSTTGC---APVRELQCTGNEKQCATFMGRASRPGD-SVRGYTVYACATKDACEVGISSMEGTKVSQFD-LKCSDPIKV----PNGYKCDECYTDQSSDSC---TPTGEVECTGKQNTCTSSSGNATIPGE-FLKPYSLKACVTQDYCELLLSM--ATQIDSDE-LLCI PAKKL----PNGYKCEDCFTDQSANGC---TSTRRIQCTGKENTCSSFYGISSRPGE-RAKRYSSKGCATSDVCTI IGVFSLAGTQALDYQ-IKCLPALKV-----

B
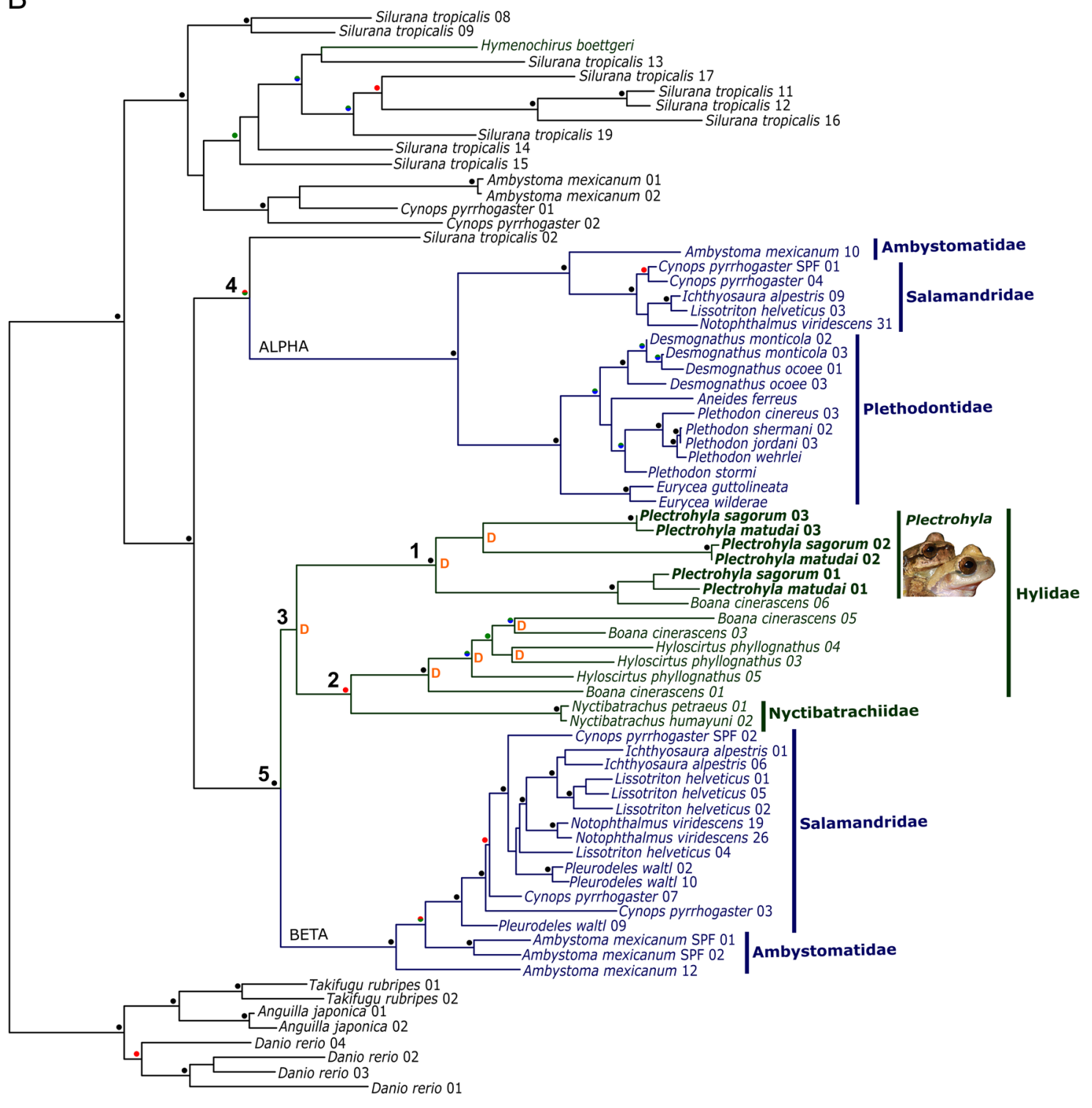

Fig. 4 (See legend on previous page.) 
Maximum Likelihood analyses resulted in a single best tree $(-\ln L=21,679.364)$, showing two well-supported clades of salamander pheromones (Fig. 4B, alpha and beta), each grouping with an anuran lineage (both representing speciation events; Fig. 4B, branches 4 and 5, respectively). Our top-expressed sequences of $P$. sagorum and $P$. matudai all fall into a single clade (together with one Boana sequence; Fig. 4B, node 1), which is the sister lineage (not strongly supported; presenting a duplication event) of the remaining anuran SPFs in the beta clade (represented by node 2).

\section{Discussion}

It has been suggested that male tree frogs of the Plectrohyla guatemalensis species group transfer allohormone pheromones from their lips into the female's skin by scratching their mating partners with their teeth during amplexus, i.e. via traumatic mating [31, 39]. The results of our study support this hypothesis. In the lips of all three examined species, we identified specialized mucus glands (SMGs), a type of sexually dimorphic skin gland, that has been described in various amphibian species (including another Plectrohyla species [33]). In several anurans which bring their SMGs in direct contact with the female's nares during mating [8] as well as in plethodontid salamanders known for transdermal transmission [40] these glands have been shown to produce proteins that are involved in chemical communication. In Plectrohyla the ducts of the SMGs exit through the epidermis onto the inner and outer lips (also see [33]). This way the gland content can be easily applied into the scratches caused by the teeth when the lips are pulled over the females' skin (also see discussion in [33]). The strong positive staining of the SMGs with Coomassie Brilliant Blue R-250 indicates a proteinaceous content of the glands, and the PAS-positive staining suggests that these proteins may contain carbohydrate chains. Combined, these results hint towards a potential glycoprotein allohormone pheromone content, as previously shown for other breeding glands [8, 41-43].

When analysing the protein content of the glands, we found several proteins whose potential role during reproduction requires further examination (see Table 3), and identified highly expressed sodefrin precursor-like factors in the frog lips as prime allohormone pheromone candidates. The evolution of SPF as a pheromone system has already been well investigated for some amphibians. It is known to have a history of gene duplications of which the derived proteins of two gene lineages (alpha and beta, differing in cysteine patterns, for details see [44]) were shown to perform a pheromone function in salamanders $[25,45]$. Furthermore, a recent study showed that multiple families of both terrestrially and aquatically reproducing anurans also independently recruited SPF proteins, most likely for chemical sexual communication. The recruitment of this potential pheromone happened when the evolution of the male breeding gland location and courtship behavior allowed transmission of its secretion to the female's nares [8]. In our study we compared the SPF proteins found in the Plectrohyla lip glands with those nasally delivering anurans as well as the same set of urodelan SPF sequences used before [8], in order to further estimate the evolution of chemical communication roles for SPF. Our phylogenetic tree is congruent with previous analyses of amphibian SPFs $[8,45]$, showing well-supported clades of alpha and beta salamander pheromones (Fig. 4B, indicated with alpha and beta). Notung analysis confirms that the groupings of each of these salamander clades with an anuran lineage represent the speciation of anurans from salamanders (Fig. 4B, nodes 4 and 5), and therefore represent amphibian alpha and beta clades. While the only anuran SPF sequence not derived from adult gland tissue falls into the alpha clade (Silurana tropicalis 02, see Additional file 2), all SPFs extracted from anuran breeding glands (Fig. 4B, marked green) cluster with the beta clade of salamander pheromones. Interestingly, our top-expressed Plectrohyla sequences all fall in a clade for which only a single frog SPF was currently known (Boana cinerascens 06; Fig. 4B, branch 1). This sequence, according to our Notung analysis, is orthologous with one of each Plectrohyla species sequences (Plectrohyla sagorum 01 and Plectrohyla matudai 01). Also, the other two Plectrohyla sequences show orthology between both species (i.e. both sequences 02 and 03, respectively; see Fig. 4B). The clade including all Plectrohyla (and one Boana) sequences is the sister lineage to all other beta SPFs extracted from anuran breeding glands (Fig. 4B, marked green), i.e. two hylid and two nyctibatrachid species [8]. These analyses thus indicate that our Plectrohyla SPF sequences stem from a duplication that happened in anurans (Fig. 4B, node 3) before the divergence of Hyloidea (Nobleobatrachia) from Ranoidea (Natatanura) (Fig. 4B, node 2), i.e. earlier than 155 million years ago [46]. It is possible that this duplication in early anuran evolution represents a co-option of betaSPF to a new delivery mode or function in chemical communication, but this cannot be confirmed at this point. Our overall results however suggest that, in extant Plectrohyla, these SPF proteins are delivered to the female transdermally, thus bypassing the olfactory system.

Our findings entail the intriguing hypothesis that SPF proteins not only recurrently acquired chemical communication functions in amphibians, but that reception by the female also independently evolved both vomeronasal and transdermal routes in salamanders and frogs. Indeed, in salamanders of the family Plethodontidae, SPF 
is one of three known protein pheromones secreted from specialized breeding glands [47], and transdermal allohormone pheromone delivery through traumatic mating, which can be found in all genera, is the ancestral delivery mode in this family. Delivery by slapping the mental glands onto the nostrils of the female is regarded as a derived mode and has only been found in a single genus (Plethodon [48]). Species in this genus are also known to be the only ones secreting the pheromone plethodontid receptivity factor (PRF) in their glands, which appears to be a replacement for SPF in this group [49]. SPF, on the other hand, has been shown to be expressed in the glands of several plethodontid genera, including those exclusively using the ancestral transdermal delivery mode [50]. SPF increases the female receptivity in one of these species (Desmognathus ocoee) after diffusion through the skin [51]. In other investigated urodelan families (Salamandridae, Ambystomatidae), transdermal delivery does not exist, and SPF was not replaced, but is delivered through the water or directly onto the nares of the female during amplexus $[44,45]$. The same is the case for anuran species known to express SPF in their breeding glands: they either press their glands onto or next to the female nares before and during amplexus, or they wave them through the water towards the female [8]. Although we have some observations regarding the mating behaviour of Plectrohyla sagorum, we only saw the male rubbing his teeth and lips over the head and back of the female while they were already in amplexus. We do not know if these frogs additionally present their glands to the female before entering amplexus (e.g. by pressing their inflared lips onto her nares), as has been shown in other hylid species $[8,52]$. Due to the strong evidence of scratching behaviours as well as the high SPF expression in the lips which are rubbed through the scratches, we suggest transdermal delivery (i.e. being part of the traumatic mating [9]), which would define SPF as an allohormone pheromone in Plectrohyla. A possible effect of SPF in Plectrohyla may be the reduction of time spent in amplexus, e.g. by accelerating oviposition. However, an experimental evaluation, e.g. through mating set-ups with and without SPF delivery, is still pending. Besides salamanders and frogs using their teeth for transdermal allohormone pheromone delivery, it has also been suggested that frog species that possess nuptial pads on their fingers (including gland tissue and often spines), use these secondary sexual characters as traumatic mating devices during amplexus [53]. For one species the gland content of the nuptial pads has been described. Even though a potential allohormone pheromone protein found in these glands (called amplexin) shares similarities with a known salamander pheromone, SPF was not found here [54].
In Plethodontidae, it has been observed that the blood vessels of peripheral circulation close to the skin dilate during courtship [55], possibly supporting the transportation of gland secretions [56]. A similar scenario is conceivable for Plectrohyla frogs: if the SPF proteins are released directly into the blood stream, they may bypass the need for central processing, and possibly directly bind to tissue- and organ-specific receptors, $[13,57]$ e.g. at the ovaries. Here they may directly influence physiological processes, such as oviposition. However, the possibility that they are also centrally processed (via different pathways than pheromones delivered over the nares) cannot be ruled out at this point and the identification of (allohormone) pheromone binding sites remains a challenging task for future studies.

\section{Conclusion}

Our study confirms the performance of traumatic mating, i.e. the wounding of females with specialized male devices (here the teeth) in hylids and suggests the delivery of proteins belonging to an early diverged anuran clade of SPFs as allohormone pheromones during amplexus. Although the exact effects of these molecules in anurans remain unknown [8] and although SPF has been shown to evoke various effects in urodelan females (such as following behaviour, cloacal gaping or courtship acceleration [44]), all essentially come down to shortening the courtship duration. Being phylogenetically nested among well-established urodelan SPF pheromones (Fig. 4B), we propose a similar role for the SPFs found in Plectrohyla. Yet, their processing after release into the circulatory system and the potential physiological or behavioural changes triggered in the female still await further research.

\section{Methods}

\section{Study species and collection sites}

During August of 2015 we collected adult frogs of three of the 19 species of the Plectrohyla guatemalensis group (Hylidae, Hylinae, Hylini) from the Nuclear Central American highlands in Chiapas, Mexico. Twelve male and one female $P$. sagorum, three male and one female $P$. matudai as well as one female P. hartwegi were collected in the Sierra Madre de Chiapas. We assured that frogs were in breeding mood, since all males but one $P$. sagorum were calling when we found them. The male that did not call was already in amplexus with a female. The couple was kept in captivity for $24 \mathrm{~h}$ and regularly checked before sacrificed. All frogs were euthanized injecting $2 \%$ lidocaine $\left(\mathrm{PiSA}^{\circledR}\right)$. Because P. hartwegi males do not have vocal sacs nor vocal slits and therefore do not call [58], we had difficulties to find males of this species. We loaned three males together with the 
female specimen which was shown to have conspicuous scratches on head and back [31] from the museums. Due to a lack of $P$. matudai-samples for histological sectioning, we further loaned one male specimen of this species, too.

\section{Teeth morphology and scar analysis}

In order to compare between sexes, we measured the length of 17-26 maxillary and premaxillary teeth of each, one male and one female of each of the three species. For this purpose, pictures of the teeth were taken, either by pushing back the upper lip or after removing it for histological analysis (see below). All well visible teeth were measured from the gingiva (not including teeth roots visible through the gum) to the tip of the tooth using the ImageJ1.47t software [59] and the mean teeth length $( \pm \mathrm{SD})$ was calculated. Using the same measurement methods, we additionally compared the distance between parallel scars found on female's backs (being suggested to derive from male's teeth [31]) with the distance between teeth of conspecific males.

\section{Histological sectioning of lip tissue}

To examine the swollen lips histologically, specimens were fixed in $4 \%$ formaldehyde and preserved in $70 \%$ $\mathrm{EtOH}$ after fixation. We removed a ca. $10 \mathrm{~mm}$ long and $3 \mathrm{~mm}$ wide strip of skin from the upper lip and a ca. $5 \times 5 \mathrm{~mm}$ sized piece of dorsal skin from the shoulder region as a control. Samples were dehydrated in a graded series of ethanol (70-100\%), paraffin-embedded, cut at $5 \mu \mathrm{m}$ with a rotary microtome and mounted onto microscope slides. All sections were stained with Periodic acid-Schiff (PAS) for the detection of mucins [60], glycogens [61] and neutral glycoproteins [62]. Male lip sections were further stained with Coomassie Brilliant Blue R-250 for detection of proteins [63]. Samples were examined with a Nikon eclipse 90i microscope and images were captured with a Nikon DS-Fil camera and processed with NIS-Elements BR3.2. In order to compare the glandular region in the lip between males and females, we measured the thickness from the epidermis to the deepest internal glands on the three widest spots on a random slide, using ImageJ1.47t [59]. We further measured the greatest diameter of the five biggest specialized breeding glands of the males of each of the three species.

\section{Whole transcriptome sequencing (RNAseq) and expression analysis}

To identify potential allohormone pheromone expression, the lips of four freshly euthanized male $P$. sagorum (one of which was in amplexus with a female before, see above) and two P. matudai were placed into $1 \mathrm{ml}$
RNAlater (Life Technologies) each and stored at $0-5{ }^{\circ} \mathrm{C}$ during transportation and then at $-20{ }^{\circ} \mathrm{C}$ until RNA isolation. The total RNA (pooled by species) was extracted using the RNeasy Plus Universal Mini Kit (Qiagen). De novo transcriptome sequencing was performed at DNAvision, Gosselies, Belgium. A paired-end cDNA sequencing library (75 bp) was constructed using the Illumina TruSeq RNA sample preparation kit for sequencing on the Illumina HiSeq2000 platform (Illumina, San Diego, California). Adaptor sequences and low quality bases were trimmed using Trim-Galore v0.5.0 [64] allowing a minimum read size of 25 base pairs and a phred score $>33$. Low-quality regions were removed with Trimmomatic v0.38 [65], using the default settings and retaining reads with a minimum length of 25 base pairs and a phred score $>20$. Rcorrector v1.03 [66] was used for identification and removal of random Illumina sequencing errors. For each sample, we generated three de novo assemblies: two using SPAdes v3.12 with kmer sizes 25 and 53 [67], and one with Trinity v2.8.5 [68]. Subsequently, we merged all three assemblies using the EvidentialGene tr2aacds pipeline [69] in order to reduce the levels of transcript redundancy. To assess the completeness and redundancy of our assemblies, we analysed them before and after merging with BUSCO v3.0.2 [70] (using the vertebrata database) and calculated contigs metrics with TransRate v1.0.3 [71] (see Additional file 2). All transcripts were annotated with the Identical Protein Groups (IPG) database from NCBI, which was filtered to contain only vertebrate sequences, using the Blastx mode of Diamond v0.9.22 [72]. Read alignment and expression calculation was done with Kallisto v0.42.4 [73]. We then manually checked all transcripts for known amphibian protein pheromones (i.e. amplexin, imorin, persuasion, plethodontid modulating factor, plethodontid receptivity factor, silefrin, sodefrin, sodefrin precursor-like factors, splendiferin) and further identified all putative secretory proteins by searching the amino-acid sequences (obtained through transdecoder v5.5.0, imbedded in EvidentialGene) for proteins which either have a predicted signal peptide (identified with SignalP v5.0 under default parameters [74]), or were identified as soluble and extracellular (using DeepLoc-1.0 [75]). All secretory proteins $>50$ TPM where then manually categorized, and while those that are typically expressed in (skin) tissue (e.g. house-keeping genes, ribosomal proteins or keratins) were not further pursued, those that stood out for being sex specific (e.g. being usually expressed in sexspecific tissues) or for normally being connected to other organs (e.g. gut tissues), were grouped in functional categories (see Table 3). The total expression values of these groups were calculated by adding up the TPM values. 


\section{Molecular phylogenetics of allohormone pheromone candidates}

For those of the Plectrohyla species where whole transcriptome sequencing identified highly elevated expression of sodefrin precursor-like factor (SPF) we chose the three highest expressed SPF-amino acid sequences (GenBank accession numbers: OL598420 - OL598425). We combined these sequences with known SPF-protein-sequences from other anurans (Hylidae, Nyctibatrachidae and Pipidae) and urodeles (Salamandridae, Plethodontidae, Ambystomatidae) as well as a set of genomic sequences of 2-domain-TFPs of amphibians and teleost fish (see Additional file 1; also compare data used in [8]). The group of fish sequences were chosen as outgroup $[45,76]$. After comparison of different alignment programs and settings, sequence alignment was done in MAFFT v.7 using the L-INS-I method [77]. Phylogenetic relationships were estimated under maximum likelihood with IQ-TREE [78] using FLU + F + R4 as best-fitted model assigned by ModelFinder [79] To assess branch support at each node we used the ultrafast bootstrap function with 1000 replicates (UFBoot2; [80]), as well as SH-like approximate likelihood ratio tests (SH-aLRT, 1000 replicates; [81]) and approximate Bayes tests (aBayes; [82]). A speciation-duplication analysis was performed using Notung 2.9 [83].

\section{Supplementary Information}

The online version contains supplementary material available at https://doi. org/10.1186/s12983-021-00445-6.

Additional file 1. Species, accession numbers and tissue-origin of the 2D-TFP sequences used in the maximum likelihood tree (Fig. 4).

Additional file 2. Statistics of the de novo transcriptome assemblies performed with the lip tissue RNA samples from P. matudai and P. sagorum.

\section{Acknowledgements}

We are very grateful to Evan Twomey for his help in the field and to Lara Hagemann and Carmen Meyer for their help with the histological sections. We thank Sunita Janssenswillen, Margo Maex, Ines Van Bocxlaer and Dag Treer for their general help and support in the lab. We further thank Jesse Delia, Tim Burkhart and Jon Campbell for helpful advises where to find Plectrohyla in the wild, and Rafe Brown, Gregory Schneider and Gunther Köhler for loaning us the museum specimens.

\section{Authors' contributions}

LMS and FB designed the study, LMS collected the specimens and conducted the lab work, AM and LMS performed the histological sectioning, LMS and FB analyzed the data and wrote the manuscript. RCE and ARB helped obtaining research permits and finalizing the manuscript. All authors read and approved the final version of the manuscript.

\section{Funding}

Open Access funding enabled and organized by Projekt DEAL. This study was funded by a Forschungsstipendium of the Deutsche Forschungsgemeinschaft, DFG (to LMS; SCHU 3066/1-1), Fonds voor Wetenschappelijk OnderzoekVlaanderen (FWO research project G020318N to FB and AM), and the Strategic Research Program of the Vrije Universiteit Brussel (SRP30 to FB).

\section{Availability of data and materials}

The raw reads generated and analysed during the current study have been deposited in the European Nucleotide Archive (ENA) under project accession number PRJEB4879.

\section{Declarations}

\section{Ethics approval and consent to participate}

Research and collection permits were issued by the Secretaría de Medio Ambiente y Recursos Naturales in Mexico (SEMARNAT; Research Permit No. SGPA/DGVS/05641/15 and SGPA/DGVS/04149/15). Museum specimen numbers: P. hartwegi UMMZ152864, UMMZ129885, KU190240 and KU19024; P. matudai: SMF84556.

\section{Consent for publication}

We have received consent from Evan Twomey and Sean M. Rovito to use one image taken by each of them for our figures (ET: Fig. 1C; SMR: Fig. 2A).

\section{Competing interests}

The authors declare that they have no competing interests.

\section{Author details}

${ }^{1}$ Department of Wildlife-/Zoo-Animal-Biology and Systematics, Faculty of Biological Sciences, Goethe University Frankfurt, Max-von-Laue-Str. 13, 60438 Frankfurt/Main, Germany. ${ }^{2}$ Wild life Health, Ghent University, Salisburylaan 133, 9820 Merelbeke, Belgium. ${ }^{3}$ Laboratorio de Zoología, Facultad de Ciencias Naturales, Universidad Autónoma de Querétaro, Avenida de Las Ciencias S/N, Santa Fe Juriquilla, C. P. 76230 Querétaro, Mexico. ${ }^{4}$ Laboratorio de Ecología de Poblaciones, Centro de Investigaciones Biológicas, Instituto de Ciencias Básicas E Ingeniería, Universidad Autónoma del Estado de Hidalgo, Km 4.5 carretera Pachuca-Tulancingo, 42184, Mineral de La Reforma, Hidalgo, Mexico. ${ }^{5}$ Amphibian Evolution Lab, Biology Department, Vrije Universiteit Brussel (VUB), Pleinlaan 2, 1050 Brussels, Belgium.

Received: 15 September 2021 Accepted: 9 November 2021 Published online: 25 November 2021

\section{References}

1. Bradbury JW, Vehrencamp SL. Principles of animal communication. Massachusetts: Sunderland; 2011

2. Wyatt TD. Pheromones and animal behaviour: chemical signals and signatures. Cambridge: Cambridge University Press; 2014.

3. Karlson P, Lüscher M.'Pheromones': a new term for a class of biological active substances. Nature. 1959;183:55-6.

4. Alberts AC. Constraints on the design of chemical communication systems in terrestrial vertebrates. Am Nat. 1992;139:62-89.

5. Hurst JL, Robertson DHL, Tolladay U, Beynon RJ. Proteins in urine scent marks of male house mice extend the longevity of olfactory signals. Anim Behav. 1998;55:1289-97.

6. Vickers NJ. Mechanisms of animal navigation in odor plumes. Biol Bull. 2000;198:203-12.

7. Treer D, Van Bocxlaer I, Matthijs S, Du Four D, Janssenswillen S, Willaert $\mathrm{B}$, et al. Love is blind: indiscriminate female mating responses to male courtship pheromones in newts (Salamandridae). PLoS ONE. 2013;8:e56538.

8. Bossuyt F, Schulte LM, Maex M, Janssenswillen S, Novikova PY, Biju $\mathrm{SD}$, et al. Multiple independent recruitment of sodefrin precursorlike factors in anuran sexually dimorphic glands. Mol Biol Evol. 2019;36:1921-30.

9. Lange R, Reinhardt K, Michiels NK, Anthes N. Functions, diversity, and evolution of traumatic mating. Biol Rev. 2013;88:585-601.

10. Ruther J, Steidle JL. "Allohormones": a new class of bioactive substances or old wine in new skins? J Comp Physiol A. 2002;188:161-2.

11. Koene JM, ter Maat A. Allohormones: a class of bioactive substances favoured by sexual selection. J Comp Physiol A. 2001;187:323-6.

12. Koene JM, ter Maat $\mathrm{A}$. The distinction between pheromones and allohormones. J Comp Physiol A. 2002;188:163-4. 
13. Wyatt TD. Pheromones and signature mixtures: defining species-wide signals and variable cues for identity in both invertebrates and vertebrates. J Comp Physiol A. 2010;196:685-700.

14. Chase R, Blanchard KC. The snail's love-dart delivers mucus to increase paternity. Proc R Soc London B. 2006;273:1471-5.

15. Koene JM, Pförtner T, Michiels NK. Piercing the partner's skin influences sperm uptake in the earthworm Lumbricus terrestris. Behav Ecol Sociobiol. 2005;59:243-9.

16. Palmer CA, Hollis DM, Watts RA, Houck LD, McCall MA, Gregg RG, et al. Plethodontid modulating factor, a hypervariable salamander courtship pheromone in the three-inger protein superfamily. FEBS J. 2007:274:2300-10.

17. Houck LD, Bell AM, Reagan-Wallin NL, Feldhoff RC. Effects of experimental delivery of male courtship pheromones on the timing of courtship in a terrestrial salamander, Plethodon jordani (Caudata: Plethodontidae). Copeia. 1998:1998:214-9.

18. Rollmann SM, Houck LD, Feldhoff RC. Proteinaceous pheromone affecting female receptivity in a terrestrial salamander. Science. 1999;285:1907-9.

19. Arnold SJ, Houck LD. Courtship pheromones: evolution by natural and sexual selection. In: Nitecki MH, editor. Biochem Asp Evol Biol. Chicago: University of Chicago press; 1982. p. 173-211.

20. Verrell P. Bracketing the extremes: courtship behaviour of the smallest - and largest - bodied species in the salamander genus Desmognathus (Plethodontidae: Desmognathinae). J Zool. 1999;247:105-11.

21. Houck LD, Reagan NL. Male courtship pheromones increase female receptivity in a plethodontid salamander. Anim Behav. 1990;39:729-34.

22. Woodley SK. Pheromonal communication in amphibians. J Comp Physiol A. 2010;196:713-27.

23. Woodley SK, Staub NL. Pheromonal communication in urodelan amphibians. Cell Tissue Res. 2021:383:1-19.

24. Woodley S. Chemosignals, hormones, and amphibian reproduction. Horm Behav. 2015:68:3-13.

25. Van Bocxlaer I, Treer D, Maex M, Vandebergh W, Janssenswillen S, Stegen $G$, et al. Side-by-side secretion of Late Palaeozoic diverged courtship pheromones in an aquatic salamander. Proc R Soc London B. 2014;2015(282):2960.

26. Maex M, Van Bocxlaer I, Mortier A, Proost P, Bossuyt F. Courtship pheromone use in a model urodele, the Mexican axolotl (Ambystoma mexicanum). Sci Rep 2016:6:20184

27. Faivovich J, Haddad CFB, Garcia PCA, Frost DR, Campbell JA, Wheeler WC. Systematic review of the frog family Hylidae, with special reference to Hylinae: phylogenetic analysis and taxonomic revision. Bull Am Museum Nat Hist. 2005;204:1-240.

28. Faivovich J, Pereyra MO, Luna MC, Hertz A, Blotto BL, Vásquez-Almazán $C R$, et al. On the monophyly and relationships of several genera of Hylini (Anura: Hylidae: Hylinae), with comments on recent taxonomic changes in hylids. South Am J Herpetol BioOne. 2018;13:1-32.

29. Duellman WE, Campbell JA. Two new species of Plectrohyla from Guatemala (Anura: Hylidae). Copeia. 1984;1984:390-7.

30. Bumzahem CB, Smith HM. Additional records and descriptions of Mexican frogs of the genus Plectrohyla. Herpetologica. 1954;10:61-6.

31. Duellman WE, Campbell JA. Hylid frogs of the genus Plectrohyla: systematics and phylogenetic relationships. Misc Publ Museum Zool Univ Michigan. 1992;181:1-32.

32. Barrio-Amorós CL, Grünwald Cl, Franz-Chavez H, Mendoza AM, La Forest BT. Notes on natural history and call description of the critically endangered Plectrohyla avia (Anura: Hylidae) from Chiapas. Mexico Amphib Reptile Conserv. 2016;10:11-7.

33. Luna MC, Vásquez-Almazán CR, Faivovich J, Brunetti AE. Gland composition in sexually dimorphic skin structures of two species of Hylid frogs: Plectrohyla guatemalensis and Ptychohyla hypomykter. Amphibia-Reptilia Brill. 2019;40:523-9.

34. Wells KD. The social behaviour of anuran amphibians. Anim Behav. 1977;25:666-93.

35. D'Amore A, Kirby E, Hemingway V. Reproductive interference by an invasive species: an evolutionary trap. Herpetol Conserv Biol. 2009:4:325-30

36. Benard MF. Predators and mates: conflicting selection on the size of male Pacific treefrogs (Pseudacris regilla). J Herpetol. 2007;41:317-20.
37. Bowcock H, Brown GP, Shine R. Beastly bondage: the costs of amplexus in cane toads (Bufo marinus). Copeia. 2009;2009:29-36.

38. Brizzi R, Delfino G, Pellegrini R. Specialized mucous glands and their possible adaptive role in the males of some species of Rana (Amphibia, Anura). J Morphol. 2002;254:328-41.

39. Wells KD. The ecology and behavior of amphibians. Chicago: University of Chicago Press; 2007

40. Sever DM. Ultrastructure of the mental gland of the Red-Backed Salamander, Plethodon cinereus (Amphibia: Plethodontidae). Acta Zool. 2017;98:154-62.

41. Thomas EO, Tsang L, Licht P. Comparative histochemistry of the sexually dimorphic skin glands of anuran amphibians. Copeia. 1993;1993:133-43.

42. Romero de Perez G, Ruiz-Carranza PM. Histologia, histoquímica y estructura fina de la glandula mentoniana de dos especies de Hyla (grupo bogotensis) y del antebrazo de Phrynopus adenobatrachius. Rev la Acad Colomb ciencias exactas, físicas y Nat. 1996;20:575-84.

43. Brunetti AE, Hermida GN, Luna MC, Barsotti AMG, Jared C, Antoniazzi $M M$, et al. Diversity and evolution of sexually dimorphic mental and lateral glands in Cophomantini treefrogs (Anura: Hylidae: Hylinae). Biol J Linn Soc. 2015;114:12-34.

44. Bossuyt F, Maex M, Treer D, Schulte LM, Van Bocxlaer I, Janssenswillen S. Chemistry between salamanders: evolution of the SPF courtship pheromone system in Salamandridae. In: Buesching CD, editor. Chem Signals Vertebr 14. Springer; 2019. p. 205-20.

45. Janssenswillen S, Vandebergh W, Treer D, Willaert B, Maex M, Van Bocxlaer I, et al. Origin and diversification of a salamander sex pheromone system. Mol Biol Evol. 2015;32:472-80.

46. Kumar S, Stecher G, Suleski M, Hedges SB. TimeTree: a resource for timelines, timetrees, and divergence times. Mol Biol Evol. 2017:34:1812-9.

47. Kiemnec-Tyburczy KM, Watts RA, Gregg RG, von Borstel D, Arnold SJ. Evolutionary shifts in courtship pheromone composition revealed by EST analysis of plethodontid salamander mental glands. Gene. 2009:432:75-81.

48. Houck LD, Arnold SJ. Courtship and mating behavior. In: Sever DM, editor. Reprod Biol phylogeny Urodela. Science Publishers USA; 2003. p. 383-424.

49. Wilburn DB, Bowen KE, Feldhoff PW, Feldhoff RC. Proteomic analyses of courtship pheromones in the redback salamander, Plethodon cinereus. J Chem Ecol. 2014;40:928-39.

50. Palmer CA, Watts RA, Houck LD, Picard AL, Arnold SJ. Evolutionary replacement of components in a salamander pheromone signaling complex: more evidence for phenotypic-molecular decoupling. Evolution (N Y). 2007;61:202-15.

51. Houck LD, Watts RA, Mead LM, Palmer CA, Arnold SJ, Feldhoff PW et al. A candidate vertebrate pheromone, SPF, increases female receptivity in a salamander. In: Hurst JL, Beynon RJ, Roberts SC, Wyatt TD, editors., et al., Chem Signals Vertebr 11. Springer; 2008. p. 213-21.

52. Brunetti AE, Taboada C, Faivovich J. The reproductive biology of Hypsiboas punctatus (Anura: Hylidae): male territoriality and the possible role of different signals during female choice. Salamandra. 2014;50:1-10.

53. Luna MC, Mcdiarmid RW, Faivovich J. From erotic excrescences to pheromone shots: structure and diversity of nuptial pads in anurans. Biol J Linn Soc. 2018;124:403-46.

54. Willaert B, Bossuyt F, Janssenswillen S, Adriaens D, Baggerman G, Matthijs $S$, et al. Frog nuptial pads secrete mating season-specific proteins related to salamander pheromones. J Exp Biol. 2013;216:4139-43.

55. Organ JA. The courtship and spermatophore of the salamander Plethodon glutinosus. Copeia JSTOR. 1960;1960:34-40.

56. Organ JA. Studies of the local distribution, life history, and population dynamics of the salamander genus Desmognathus in Virginia. Ecol Monogr. 1961;31:189-220.

57. Doty KA, Wilburn DB, Bowen KE, Feldhoff PW, Feldhoff RC. Co-option and evolution of non-olfactory proteinaceous pheromones in a terrestrial lungless salamander. J Proteomics. 2016;135:101-11.

58. Duellman WE. The hylid frogs of Middle America, Vol. 2. Monogr Nat Hist Museum Univ Kansas. Kansas; 1970;1:753.

59. Rasband WS. ImageJ, U. S. National Institutes' of Health [Internet]. Bethesda, Maryland, USA; 1997. http://imagej.nih.gov/ij/1997-2011 
60. McManus JFA. Histological demonstration of mucin after periodic acid. Nature. 1946;158:202.

61. Lillie RD. Studies on the preservation and histologic demonstration of glycogen. J Tech Methods. 1947;27:23-61.

62. Mowry RW. The special value of methods that color both acidic and vicinal hydroxyl groups in the histochemical study of mucins. Ann N Y Acad Sci. 1963;106:402-23.

63. Kiernan JA. Histological and histochemical methods: theory and practice. Oxford: Butterworth-Heinemann; 2003.

64. Babraham Bioinformatics. Trim Galore [Internet]. 2016. http://www. bioinformatics.babraham.ac.uk/projects/trim_galore/

65. Bolger AM, Lohse M, Usadel B. Trimmomatic: a flexible trimmer for Illumina sequence data. Bioinformatics. 2014;30:2114-20.

66. Song L, Florea L. Rcorrector: efficient and accurate error correction for Illumina RNA-seq reads. Gigascience. 2015;4:48.

67. Bankevich A, Nurk S, Antipov D, Gurevich AA, Dvorkin M, Kulikov AS, et al. SPAdes: a new genome assembly algorithm and its applications to single-cell sequencing. J Comput Biol. 2012;19:455-77.

68. Grabherr MG, Haas BJ, Yassour M, Levin JZ, Thompson DA, Amit I, et al. Trinity: reconstructing a full-length transcriptome without a genome from RNA-Seq data. Nat Biotechnol. 2011;29:644.

69. Gilbert D. EvidentialGene: tr2aacds, mRNA transcript assembly software [Internet]. 2013. http://arthropods.eugenes.org/EvidentialGene/

70. Simão FA, Waterhouse RM, loannidis P, Kriventseva EV, Zdobnov EM. BUSCO: assessing genome assembly and annotation completeness with single-copy orthologs. Bioinformatics. 2015;31:3210-2.

71. Smith-Unna R, Boursnell C, Patro R, Hibberd JM, Kelly S. TransRate: reference-free quality assessment of de novo transcriptome assemblies. Genome Res. 2016;26:1134-44.

72. Buchfink B, Xie C, Huson DH. Fast and sensitive protein alignment using DIAMOND. Nat Methods. 2015:12:59-60.

73. Bray NL, Pimentel H, Melsted P, Pachter L. Near-optimal probabilistic RNA-seq quantification. Nat Biotechnol. 2016;34:525.

74. Armenteros JJA, Tsirigos KD, Sønderby CK, Petersen TN, Winther O, Brunak S, et al. SignalP 5.0 improves signal peptide predictions using deep neural networks. Nat Biotechnol. 2019;37:420.

75. Almagro Armenteros JJ, Sønderby CK, Sønderby SK, Nielsen H, Winther O. DeepLoc: prediction of protein subcellular localization using deep learning. Bioinformatics. 2017;33:3387-95.

76. Grant T. Outgroup sampling in phylogenetics: severity of test and successive outgroup expansion. J Zool Syst Evol Res. 2019;57:748-63.

77. Katoh K, Standley DM. MAFFT multiple sequence alignment software version 7: improvements in performance and usability. Mol Biol Evol. 2013;30:772-80.

78. Nguyen L-T, Schmidt HA, Von Haeseler A, Minh BQ. IQ-TREE: a fast and effective stochastic algorithm for estimating maximum-likelihood phylogenies. Mol Biol Evol. 2015;32:268-74.

79. Kalyaanamoorthy S, Minh BQ, Wong TKF, von Haeseler A, Jermiin LS. ModelFinder: fast model selection for accurate phylogenetic estimates. Nat Methods. 2017;14:587

80. Hoang DT, Chernomor O, Von Haeseler A, Minh BQ, Vinh LS. UFBoot2: improving the ultrafast bootstrap approximation. Mol Biol Evol. 2018:35:518-22.

81. Guindon S, Dufayard J-F, Lefort V, Anisimova M, Hordijk W, Gascuel O. New algorithms and methods to estimate maximum-likelihood phylogenies: assessing the performance of PhyML 3.0. Syst Biol. 2010;59:307-21.

82. Anisimova M, Gil M, Dufayard J-F, Dessimoz C, Gascuel O. Survey of branch support methods demonstrates accuracy, power, and robustness of fast likelihood-based approximation schemes. Syst Biol. 2011;60:685-99.

83. Chen K, Durand D, Farach-Colton M. NOTUNG: a program for dating gene duplications and optimizing gene family trees. J Comput Biol. Mary Ann Liebert, Inc.; 2000;7:429-47.

84. Tsetlin V. Snake venom a-neurotoxins and other 'threefinger'proteins. Eur J Biochem. 1999:264:281-6.

85. Nys Y, Guyot N. Egg formation and chemistry. In: Nys Y, Bain M, Van Immerseel F, editors. Improv Saf Qual eggs egg Prod. Elsevier; 2011. p. 83-132.

86. Saxena I, Tayyab S. Protein proteinase inhibitors from avian egg whites. Cell Mol Life Sci C. 1997:53:13-23.
87. Chouinard AJ. Pheromone variation in plethodontid salamanders. Oregon State University; 2016

88. Yamada Y, Aketa K. Ovostatin, an endogenous trypsin inhibitor of sea urchin eggs: purification and characterization of ovostatin from eggs of the sea urchin, Strongylocentrotus intermedius. Gamete Res. 1988;19:265-75.

89. Aketa K, Onitake K, Tsuzuki H. Tryptic disruption of sperm-binding site of sea urchin egg surface. Exp Cell Res. 1972;71:27-32.

90. Mann K. Proteomic analysis of the chicken egg vitelline membrane. Proteomics. 2008;8:2322-32.

91. Lee SI, Ji M-R, Jang Y-J, Jeon M, Kim JS, Park J-K, et al. Characterization and miRNA-mediated posttranscriptional regulation of vitelline membrane outer layer protein I in the adult chicken oviduct. Vitr Cell Dev Biol. 2015:51:222-9.

92. Wang Y, Bu L, Yang L, Li H, Zhang S. Identification and functional characterization of fish-egg lectin in zebrafish. Fish Shellfish Immunol. 2016;52:23-30.

93. Peavy TR, Hernandez C, Carroll EJ. Jeltraxin, a frog egg jelly glycoprotein, has calcium-dependent lectin properties and is related to human serum pentraxins CRP and SAP. Biochemistry. 2003;42:12761-9.

94. Green NM. Avidin. Adv Protein Chem. 1975:29:85-133.

95. Watanabe A, Takayama-Watanabe E. In silico identification of the genes for sperm-egg interaction in the internal fertilization of the newt Cynops pyrrhogaster. Int J Dev Biol. 2015;58:873-9.

96. Cohen DJ, Maldera JA, Weigel Muñoz M, Ernesto Jl, Vasen G, Cuasnicu PS. Cysteine-rich secretory proteins (CRISP) and their role in mammalian fertilization. Biol Res. Sociedad de Biología de Chile; 2011:44:135-8

97. Xiang X, Burnett L, Rawls A, Bieber A, Chandler D. The sperm chemoattractant "allurin" is expressed and secreted from the Xenopus oviduct in a hormone-regulated manner. Dev Biol. 2004;275:343-55.

98. Gibbs GM, Roelants K, O'bryan MK. The CAP superfamily: cysteinerich secretory proteins, antigen 5 , and pathogenesis-related 1 proteins-roles in reproduction, cancer, and immune defense. Endocr Rev. 2008:29:865-97.

99. Weiber H, Andersson C, Murne A, Rannevik G, Lindström C, Lilja H, et al. Beta microseminoprotein is not a prostate-specific protein. Its identification in mucous glands and secretions. Am J Pathol. 1990:137:593-603.

100. Laurence M. PSP94, what is it good for? Shipshaw Labs; 2018.

101. Taylor JA, Boyd SK. Thyrotropin-releasing hormone facilitates display of reproductive behavior and locomotor behavior in an amphibian. Horm Behav. 1991;25:128-36.

102. Alderete MR, Tokarz RR, Crews D. Luteinizing hormone-releasing hormone and thyrotropin-releasing hormone induction of female sexual receptivity in the lizard, Anolis carolinensis. Neuroendocrinology. 1980;30:200-5.

103. Masserano JM, King C. TRH increases locomotor activity in rats after injection into the hypothalamus. Eur J Pharmacol Elsevier. 1981;69:217-9.

104. Liu L, Burcher E. Tachykinin peptides and receptors: putting amphibians into perspective. Peptides. 2005:26:1369-82.

105. Elliott PJ, Iversen SD. Behavioural effects of tachykinins and related peptides. Brain Res. 1986;381:68-76.

106. Geary N. Glucagon and the control of appetite. Glucagon III. Springer; 1996. p. 223-38.

107. Chelikani PK, Haver AC, Reidelberger RD. Intravenous infusion of glucagon-like peptide-1 potently inhibits food intake, sham feeding, and gastric emptying in rats. Am J Physiol Integr Comp Physiol. 2005;288:R1695-706.

108. Mohan H, Unniappan S. Phylogenetic aspects of nucleobindin-2/ nesfatin-1. Curr Pharm Des. 2013;19:6929-34.

109. Banerjee RR, Rangwala SM, Shapiro JS, Rich AS, Rhoades B, Qi Y, et al. Regulation of fasted blood glucose by resistin. Science (80). 2004:303:1195-8

110. Ren J, Chen Z, Zhang W, Li L, Sun R, Deng C, et al. Increased fat mass and insulin resistance in mice lacking pancreatic lipase-related protein 1. J Nutr Biochem. 2011:22:691-8. 
Publisher's Note

Springer Nature remains neutral with regard to jurisdictional claims in published maps and institutional affiliations.
Ready to submit your research? Choose BMC and benefit from:

- fast, convenient online submission

- thorough peer review by experienced researchers in your field

- rapid publication on acceptance

- support for research data, including large and complex data types

- gold Open Access which fosters wider collaboration and increased citations

- maximum visibility for your research: over $100 \mathrm{M}$ website views per year

At BMC, research is always in progress.

Learn more biomedcentral.com/submissions 